\title{
THE IAMBIC PENTAMETER AND ITS RIVALS
}

\author{
Martin J. DuffELL
}

7 he sixteenth century witnessed the establishment of three metres as the canons of Spanish, French, and English 1 long-line verse. In Spain the first Italianate endecasílabos appeared in a volume, published in 1547, containing the poems of Juan Boscán de Almogáver (b.?1487, d. 1542) and Garcilaso de la Vega (b. 1501, d. 1536). It was the latter's verse design that served as the model for subsequent poets: Garcilaso converted the Italian endecasillabo into a metre intermediate between syllabic and stress-syllabic by imposing an iambic rhythm on the second half of the line. ${ }^{1}$ The endecasílabo succeeded the verso de arte mayor, a loosely stress-syllabic metre that had dominated long-line verse in Castilian and Galician-Portuguese since the 1380s. ${ }^{2}$ In France the alexandrin, a syllabic metre of 6 + 6 syllables, established its pre-eminence with the publication in 1558 of Les Regrets by Joachim Du Bellay (b. 1522, d. 1560). Until then, like Pierre de Ronsard (b. 1524, d. 1585), Du Bellay had composed sonnets in vers de dix of $4+6$ syllables as well as alexandrins, but in his last and greatest work all the sonnets are in the longer metre, and this subsequently became the long-line

${ }^{1}$ Gasparov uses a statistical technique termed probability modelling to show that the endecasílabo is an intermediate metre (1987: 330-32); Domínguez Caparrós confirms that all variants of the endecasílabo have an iambic rhythm in the latter part of the line (2000: 152-55).

2 The verse design of arte mayor has been the subject of considerable controversy. The line comprises two hemistichs, each with two beats and a preponderance of (amphibrachic) triple time, in which some poets gave priority to accentual regularity and others to syllabic. See Clarke 1964: 51-211, Piera 1980: 109-14, Duffell 1999a: 55-85, and Duffell in press. 
canon. The alexandrin thus emerged victorious from a battle for dominance with its shorter rival that had begun in the middle of the twelfth century. ${ }^{3}$ In England the iambic pentameter, a stresssyllabic metre also derived from the Italian endecasillabo, became the canon in the 1580s when it was reintroduced by Edmund Spenser (b. c.1552, d. 1599) and Sir Philip Sidney (b. 1554, d. 1586). ${ }^{4}$ The peculiar circumstances that led to the need for that reintroduction, and the previous lack of an English longline canon are the subject of the present article.

Before proceeding to examine those two issues, however, we should consider how metres evolve and why they endure. Hanson \& Kiparsky put forward the hypothesis, termed the principle of ' $f$ it', that metres evolve in such a way as to accommodate most of the lexicon and reflect the major phonological features of the language concerned (1996: 294). Although this principle confirms the insights of earlier scholars (in particular, Thompson 1961 and Jakobson 1973), there are notable exceptions to it; for example, the adoption of Greek quantitative dactylic hexameter denied Roman poets access to a large portion of their lexicon (Raven 1965: 11). Although the evolution of metres can hardly be unaffected by sociological factors such as emulation, fashion, and prestige, it is nevertheless true that most metrical systems employ the salient phonological features of the language concerned. Metres are also sometimes the victims of linguistic change: for example, the loss of vowel-length distinctions in Late Latin clearly affected the ability of its speakers to compose quantitative verse spontaneously (see Lote 1939: 220-22).

The French, English, and Spanish canonical long-line metres are a remarkably good fit for the phonology of their languages.

${ }^{3}$ The vers de dix was dominant c. 1020 to c. 1180 , the alexandrin c. 1180 to c. 1350 , and the vers de dix c.1350 to c.1550. See Kastner 1903: 142-48.

${ }^{4}$ A concise linguistic description of the iambic pentameter is given by Hanson \& Kiparsky, who employ the traditional term feet for the five weak/strong contrasts within the line (1996: 289n4). In this article I shall also follow the example of other metrists, such as Attridge, who proposes a single unified theory for all English metre (1982: 158-213), and describe these contrasts as beats and offbeats. 
The alexandrin employs three of the most salient features of that language's phonology: right-strength (theright-most full syllables of words is the one with a potential for stress), phrasal stress (which the loss of word stress in modern French foregrounds), and syllable-timing (syllables are allocated what is perceived as equal time in delivery). ${ }^{5}$ The combination of these three features creates a simple primary rhythm, an event (the phrasal stress on every sixth syllable) that occurs at equal time intervals (Cornulier 1995: 115). In contrast, the iambic pentameter has a different type of rhythm, a complex secondary rhythm, produced by the regular occurrence of two types of event, stronger and weaker syllables, throughout the line (Chatman 1965: 29). The iambic pentameter also employs the distinctive properties of its language: English has strong word stress (including secondary stress), a plethora of monosyllables with no fixed prominence relationship (weak/strong) between them, and stress-timing, which admits an additional light syllable (resolution) in some lines. Similarly the endecasílabo employs the salient features of the Spanish language: strong word stress (as in English), syllable-timing (as in French), and a majority of words ending in a vowel (which merges with any initial one of a following word, a feature termed synaloepha). While the endecasílabo's strict syllable count ensures that line-final stresses arrive at equal time intervals, its length (the only fixed unit has ten positions, not six) and its mid-line stresses hinder perception of this primary rhythm, which has to be supplemented by a secondary one in the second half of the line. ${ }^{6}$

${ }^{5}$ The traditional analysis of the alexandrin is that its verse design is syllabic, regulating only the number of syllables in each hemistich (six) and the type of syllable (accented) that must occur in position 6 (see, for example, Grammont 1937: 817). A number of modern writers, however, have detected metrically significant structures (syntagms or mesures) within the line and have analysed the alexandrin on this basis. Proponents of this view include Volkoff (1976), Verluyten (1982 \& 1989), and Pensom (1982 \& 2000), but Billy (1989 \& 2001) reveals the problems that such an analysis raises. Dominicy 1992 provides a modern linguistic account of the metre that confirms the traditional syllabic analysis and Cornulier explains how such a metrics of undifferentiated syllables works (1995: 111-15).

${ }^{6}$ Duecento and Trecento Italian poets composed many triple-time lines with prominent syllables in positions 4, 7, and 10. By placing stressed syllables in position 
It can be argued that French phonology ensured that a syllabic metre would become the language's long-line canon, and that the alexandrin prevailed over the vers de dix because of its greater regularity (phrasal stress on every sixth syllable) and greater length (enabling it to accommodate complex syntax more easily). It also seems reasonable to assume that the similarities between Italian and Spanish phonology played a role in the seamless transition from endecasillabo to endecasílabo. ${ }^{7}$ In English, however, linguistic change in the period 1066 to 1500 and the lack of an unbroken metrical tradition combined to make the connection between phonology and the eventual long-line canon much more problematic. In the sixteenth century there were a number of viable alternatives and, while hindsight may make the triumph of the iambic pentameter seem inevitable, its victory was clearly not foreseen at the time. A number of poets persevered with older verse designs or experimented with new ones, and some of them suited the phonology of English as well as the iambic pentameter. There were five other metres employed by sixteenth-century poets that might have become the English long-line canon and, if we include the iambic pentameter both as it had been employed in Scotland at the end of the fifteenth century, and as it reappeared in England in the last quarter of the sixteenth, we can compare seven types of line. The following analysis examines the verse designs of each and its fitness for the phonology of modern English; it also considers the role played by sociology in the evolution of the English canon: fashion, prestige, and foreign influence.

7 only when position 6 also contained one, Garcilaso made the second half of his line stress-syllabic, with no prominent syllables in odd-numbered positions after 3 (see Duffell 1999a: 37-44).

${ }^{7}$ It should be noted that the changes made by Garcilaso to the endecasillabo also occurred in the endecasillabi of Torquato Tasso (b. 1544, d. 1595); see Duffell 1991: 403-04. 


\section{The Chaucerian Line of Dunbar}

The long line of Wiliam Dunbar (b. ?1456, d. 1513) clearly meets the definition of an iambic pentameter given in Hanson \& Kiparsky 1996 and Duffell 2002. ${ }^{8}$ Its verse design can be described most economically as follows: its template has ten positions alternating weak-strong, and the correspondence rules for verse instances prescribe no mandatory mid-line word boundary. ${ }^{9}$ They also limit the size of each position to a maximum of one syllable and constrain the strong syllables (those with lexical stress in polysyllabic words and clitic groups) from appearing in weak positions. ${ }^{10}$ Although the traditional belief has been that strong positions normally contain stressed syllables and weak positions unstressed ones, Hanson \& Kiparsky show that this belief is ill-founded: unstressed monosyllables frequently occur in strong positions, and stressed monosyllable in weak ones. ${ }^{11}$

${ }^{8}$ The parametric theory of Hanson \& Kiparsky defines metres on the basis of five key features, or parameters: (1) position number, (2) orientation, (3) position size, (4) prominence site, and (5) prominence type. They give the parameters of the iambic pentameter as (1) ten, (2) right-strong, (3) one syllable or one foot (which allows two light syllables in place of one), (4) weak positions (5) strength, the lexically determined greater stress in polysyllabic words (1996: 289-93).

9 Hanson \& Kiparsky's parameters ignore the question of caesura, which they see as no part of the verse design. Duffell 2002 argues that Chaucer and later English iambic pentameter poets cultivated variety in mid-line word boundaries and that this should be recognized in the metre's definition.

10 Strong syllables are constrained from appearing in weak positions in the iambic pentameter other than: (1) line-initially and after a major syntactic boundary (justified by the closure principle of Smith 1968, which makes metrical rules more lax at the beginning of units than at their end; see Hanson \& Kiparsky 1996: 293), and (2) very exceptionally in other positions, but only when foot and word boundaries coincide (termed the bracketing condition; see Kiparsky 1977: 201-02).

11 The secondary rhythms of verse are based on the contrast between prominent and unprominent syllables; the only fixed prominence relationship in languages with dynamic accent (stress) is that found in polysyllabic words, where the primary stressed syllable must be given more stress (making it stronger than) the others. The relative stress of monosyllables (other than in clitic groups, like 'a song' or 'in tune', where the second syllable is strong) is not fixed in this way, and they may thus appear in any position in the line. A metre with strength as its prominence type allows great freedom in a language that is heavily monosyllabic (monosyllables represent more than three-quarters of all words as items in English verse; see Bradley 1970: 61-63, Tarlinskaja 1976: 14, and Duffell 2002: 305). 
Their analysis demonstrates that, while every type of syllable occurs in strong positions, strong syllables are constrained from appearing in weak ones (1996: 291). ${ }^{12}$ The story of the iambic pentameter between Chaucer and Dunbar is a curious one: it had been invented by the former in the late 1370s, but had been abandoned by English fifteenth-century poets for linguistic reasons. Since I have told that story in detail elsewhere (Duffell 1996, 2000a, 2000b, and 2002), I shall discuss it only briefly here.

Geoffrey Chaucer (b. ?1340, d. 1400) invented the iambic pentameter on his return from Italy in 1378, by promoting the favourite (iambic) rhythm of Boccaccio and Petrarch to a structural principle in his own long line. ${ }^{13}$ Chaucer's friend John Gower (b. ?1330, d. 1408) and his disciple Thomas Hoccleve (b. ?1369, d. 1426) both adopted his metre for their English long-line verse, although to Hoccleve ten syllables were clearly much more important than an iambic rhythm (see Jefferson 2000). Chaucer's successor, however, as the most esteemed poet in England was John Lydgate (b. ?1370, d. 1449), who rejected both key aspects of the new-fangled Italianate metre: isosyllabism and a uniformly iambic rhythm. Although he was clearly influenced by some of Chaucer's innovations, he returned to an older tradition of English versifying, giving his long lines five beats (divided $2+3$ ) rather than ten syllables (see Duffell

12 While a constraint on strong syllables in weak positions is the defining feature of the iambic pentameter, the content of strong positions plays a major role in determining the rhythm of individual lines. The iambic pulse becomes stronger with each strong position that contains a stressed syllable, and weaker with each one that does not, and this is the chief source of the rhythmic variety that is found in the work of the most skilled poets.

${ }^{13}$ Chaucer modified the endecasillabo's verse design by eliminating lines with accented syllables in positions 4,7 , and 10 , which have a triple-time rhythm, and 3, 6 , and 10 , where the rhythm changes from anapaestic to iambic. The chief difference between Chaucer's verse design and later iambic pentameters is that the former allows a void in initial weak positions (making headless lines). As noted above (n6), Garcilaso also avoided the 4-7-10 line; unlike Chaucer, however, he allowed 3-6-10 lines, which later poets employed even more extensively in their endecasílabos (see Dominicy in press). 
2000a: 247-48). Lydgate's apostasy was almost certainly due the impossibility of writing isosyllabic verse for recitation by readers whose syllabification of word-final schwa could not be predicted. ${ }^{14}$

Chaucer's iambic metre was kept alive in the fifteenth century by a series of Scottish poets, beginning with King James I (for nineteen years a prisoner in London, 1406-25), and including most notably Robert Henryson (b. ?1424, d. ?1506), William Dunbar (b. ?1456, d. ?1513), and Gavin Douglas (b. ?1475, d. 1522). ${ }^{15}$ Precisely why the Scottish ear fastened onto the rhythmic regularity of the London poet, when his own countrymen abandoned it along with antiquated schwa, is not clear. ${ }^{16}$ Certainly schwa loss occurred in Scots at least a century earlier than in the English of the East Midlands. ${ }^{17}$ We cannot even be sure that the Scots poets knew that Chaucer syllabified some of his final schwas: they may simply have been imitating the English poet’s many schwa-less iambic lines.

The verse design of Robert Henryson is almost, but not quite, Chaucer's iambic pentameter applied to a language in which word-final schwas are all deleted. But, while the Scottish poet's lines are more consistently iambic than Hoccleve's, they also have some features that are more typical of the French vers de dix. In particular most of Henryson's lines have a wordboundary after syllable 4 (86 per cent, compared with only 70

${ }^{14}$ The final loss of such schwas, a process begun two centuries earlier, not only prevented fifteenth-century poets writing syllabically regular verse, it also meant that readers of Chaucer's verse increasingly recited it as if it were Lydgate's, making many lines neither iambic nor decasyllabic.

15 My quotations and statistics for these poets are based on the text of Bawcutt \& Riddy 1992. A different selection of their verse, together with a short introduction, can be found in Scott 1967.

${ }^{16}$ Note that Charles Duc d'Orleans (b. 1394, d. 1464), who was a prisoner of war in England for twenty-five years (1425-50), also composed excellent Chaucerian iambic pentameters in schwa-deleted English; see Steele 1941 (for Charles's text) and Steele \& Day 1946: 47 (for comment on his metre).

17 Scots was a direct descendent of the Northumbrian dialect, which had evolved from that of the Northern Angles, but had acquired a large number of French loan words. For a concise note on the language of Henryson and Dunbar, see Bawcutt \& Riddy 1992: ix. Minkova 1991 gives a geographical and diachronic account of schwa-loss in English. 
per cent in the Canterbury Tales) and he employs lyric caesura (the second-foot inversion abhorred by most English poets) in 7 per cent of his lines (Duffell 2002: 296). ${ }^{18}$ French influence on Scottish culture was, of course, strong throughout the fifteenth century, and Henryson seems to have had one eye on Chaucer's versification and the other on that of contemporary French poets. To find fifteenth-century lines that fully meet the definition of iambic pentameter, we must turn to the work of William Dunbar, who seems to have realised that lack of caesura, and variety in the position of mid-line word-boundaries are essential features of Chaucer's verse design. ${ }^{19}$ We do not know how familiar any sixteenth-century English poet was with Dunbar's work, but we do know that none of those working in the first half of the century adopted his verse design. Instead each pursued his own vision of a long-line English metre.

\section{The Experimental Line of Wyatt}

The long lines of Sir Thomas Wyatt (b. 1503, d. 1542) include many that meet the definition of iambic pentameter, and almost as many that do not. Although he was well able to compose regularly iambic decasyllables, he often chose to do something else, as the following lines from his sonnets illustrate: (the numbers are those in Rebholz 1978): ${ }^{20}$

18 Lyric caesura, as its name implies, arose in sung verse, where stress in position 3 was relocated to the e-atone in position 4 . This was one of three ways of accommodating feminine words at the caesura in medieval French, of which only one is employed today, the elision of the $e$-atone before a vowel.

${ }^{19}$ Dunbar's language contains fewer monosyllables and more disyllables than that of other poets writing in English, including the Scottish ones. He ensures that a high proportion of his lines have no word break at position 4 by the liberal use in positions 4-5 of two Scots grammatical forms that are not available to modern English: syllabified plurals in -is and syllabified past participles in -it (see Duffell 2002: 296).

${ }^{20}$ All texts in this article are presented with the following scansion aids: (1) words are double-spaced, (2) possible caesurae are further spaced, (3) separately counted syllables are hyphenated, (4) stressed syllables more prominent than their neighbours are in bold typeface, (5) atonic monosyllables and secondary stressed syllables are underlined when they occupy a strong position, (6) void weak positions are marked ' $\mathrm{V}$ '. 
(1) The li-vely sparks that is-sue from those eyes (xxv.1)

(2) Like the im-mea-su-ra-ble moun-tains (xxIv. 1)

(3) But of ha-ting my-self that date is past (XII. 3)

(4) En-vy them be-yond all mea-sure (xxII. 4)

(5) With fei-gned vi-sage now sad now me-rry (xI.11)

(6) Who-so list to hunt, I know where is an hind (XI. 1)

(7) I fly a-bove the wind yet can I not a-rise (XVII. 3)

Instance (1) has both ten syllables to the final stress and an iambic rhythm but the remainder are clearly not iambic pentameters: (2) has 8F syllables, (4) 7F, (5) 9F, (6) 11F, (7) 12M, and (3), (5), and (6) do not have an iambic rhythm. A more detailed analysis of the twenty-two sonnets that are most certainly by Wyatt shows the following distribution of line lengths (Duffell 1991: 549): ${ }^{21}$

$$
>10 \mathrm{M} / \mathrm{F}=19 \% ; \quad 10 \mathrm{M} / \mathrm{F}=59 \% ; \quad 9 \mathrm{~F}=15 \% ; \quad<9 \mathrm{~F}=6 \% .
$$

Thus fewer than $60 \%$ of Wyatt's lines are decasyllables, unless we accept that both $10 \mathrm{~F}$ and $9 \mathrm{~F}$ are equivalent to $10 \mathrm{M}$ syllables. This creative method of accounting would make decasyllables of his 9F lines (like (5) above, where 'mer-ry' is rhymed on its second, weak syllable), but it would still leave a quarter of his lines with the wrong number of syllables.

Instance (6) above is the clearest indication that Wyatt sometimes intended other than ten syllables and/or an iambic rhythm, because it is repeated elsewhere in the poem converted into a perfect iambic pentameter by the omission of its second syllable '-so'. But (6) makes a more dramatic and effective opening: each hemistich has three prominent syllables, the falling rhythm of the first contrasting with the rising rhythm of

${ }^{21}$ These sonnets appear in the Egerton Manuscript (British Museum MS 2711) and have Wyatt's name written against them; some are believed to be, or to have emendations in, his own hand. Together with other poems attributed to Wyatt, these twenty-two sonnets were published in 1557 by Richard Tottel in his Songs and Sonnets (usually known as Tottel's Miscellany; ed. Rollins 1928-29). Tottel regularized many of Wyatt's lines in his edition, but, since Wyatt's emendations in the Egerton MS often make a line's rhythm and/or syllable count less regular, there can be no doubt that this regularity was far from the poet's metrical intention. 
the second, and this reinforces the semantic contrast in the image of predator and prey. The irregularity of this line is evidence not only of Wyatt's metrical intention but also of his superb craftsmanship. Clearly the iambic pentameter is only one possible realization of his verse design, which can be deduced only from a close study the lines that do not meet that definition. Endicott's dissertation is such a study, and she suggests that Wyatt's frequent lapses into triple time may have been in imitation of the Italian endecasillabo with its variety of rhythms (1963: 108-09). But Wyatt employs twice as many triple-time lines as Petrarch when he adapts one of the latter's poems (Rebholz, Ix; see Duffell 1991: 556). A more likely explanation is that Wyatt was as intolerant of rhythmic monotony as he was of syllabic. Endicott also supports the conclusion of Baldi 1953 that Wyatt wished to mix flowing lines (iambic pentameters, with their $2+3$ or $3+2$ stresses) and balanced, or symmetrical ones like (5) above, with its $2+2$ stresses, or (6), with its $3+3$ (1963: 72).

Another hypothesis of Wyatt's verse design is that of Rebholz, who argues that Wyatt's metrical intention was not the iambic pentameter as we know it, but a 'flexible pentameter', one in which weak positions may be occupied by zero or two syllables (1978: 44-55). Such a metre is termed a dol'nik by Tarlinskaja 1976 who classifies it according to the number of ictuses, or beats, that its verse design contains. But the number of beats in Wyatt's long line varies from 3 to 6; only 61 per cent of lines have four beats, the most common number (Duffell 1991: 554). While this may disqualify Wyatt's metre as a dol'nik, his verse does seem to work on similar principles. It is based not on syllable-count, but on beats and offbeats, and only when each of these corresponds to one syllable does an iambic pentameter result. Weak positions, or offbeats, comprising zero or two syllables are a characteristic of Lydgate's metre (Duffell 2000a: 236-40) as well as of the dol'nik, and Wyatt's metre can thus be seen as following a traditional English mode of versifying. ${ }^{22}$

22 Note that only 43 per cent of Wyatt's non-decasyllabic lines fall into any of the four categories that Schick (1889) proposes for Lydgate’s (Duffell 1991: 554-55). 
Wyatt's verse occupies a point in the history of English longline metre where everything appears to have been the meltingpot: rhyme, rhythm, stress/ strength, isosyllabism, all still have undecided futures, and all are available for experiment. In this state of flux Wyatt challenged the rules of Romance verse and often rebelled against the foreign practices of counting syllables and rhyming strong syllables. He set out to create an English line that differed significantly from its continental equivalents, one that embraced the rhythmical smoothness of the iambic pentameter when he felt it appropriate, and reverted to a traditional English pattern of beats when he felt it was not. The reason why it is so difficult to identify Wyatt's template and correspondence rules may be because he was building on a greenfield site and hovering between alternatives. In this he was not being schizophrenic but was trying to embrace diversity. In subsequent centuries his verse has been esteemed whenever diversity has been in fashion, and regularized or criticized when it was not; It is not surprising, therefore, that the present age prefers Wyatt's poetry to that of his friend and younger contemporary Surrey.

\section{The French Line of Surrey}

Henry Howard, Earl of Surrey (b. ?1517, d. 1547), also composed a number of sonnets in which he attempted to develop a suitable long-line English metre. His verse design can be illustrated by the sonnet (Keene 1985: 40), which is an imitation of Petrarch's Canzoniere, cccxx: 'Zefiro torna e'l bel tempo rimena' (Vianello 1966):

(8) The soote sea-son,

(9) With green hath clad

(10) The nigh-tin-gale

(11) And tur-tle to

(12) Sum-mer is come,

(13) The hart hath hung

(14) The buck in brake

that bud and bloom forth brings

the hill and eke the vale; with fea-thers new she sings;

her make hath told her tale.

for e-very spray now springs;

his old head on the pale;

(15) The fi-shes flete with new re-pai-rèd scale; 
(16) The ad-der all

(17) The swift swal-low

her slough a-way she slings;

(18) The bu-sy bee pur-su-eth the flies small;

(19) Win-ter is wornthat was the flo-wers' bale.

(20) And thus I see a-mong these plea-sant things

(21) Each care de-cays, and yet my sor-row springs.

The verse design of this poem is readily identifiable as the French vers de dix; it has ten positions with a mandatory wordbreak after position 4, it is right-strong with rhyme, and position size is unfailingly one syllable. The poem also employs lyric caesura, in 'sea-son' (1) and 'swal-low' (17), although this device was falling from fashion in the French poetry of Surrey's time. It may be argued that Surrey intended 'season' to be pronounced like saison in French, but this does not apply to many of the other examples in Surrey's sonnets, which involve words like 'people' (8.4) and 'weather' (8.6). The metre differs from the French vers de dix in prominence site and type: it is almost perfectly iambic as well as perfectly decasyllabic.

The metre of this poem is an iambic version of the vers de dix; it is not iambic pentameter because it lacks a key feature of that metre, which is neglected by Hanson \& Kiparsky 1996. English Poets composing iambic pentameter make their lines a balanced mixture of pausing lines (those with a word-break immediately after position 4, as in the French vers de dix) and running ones (those with no such break, as in the majority of Italian endecasiIlabi; see Duffell 2002: 292 and 305). There are no running lines in the sonnet quoted above, and Surrey is simply regularizing English word stress within the French line. ${ }^{23}$ English word stress, however, seems to have given Surrey a problem at the caesura: sometimes he employs lyric caesura (for example, Poems 8 and 9), in some he employs running lines (for example, 11 and 13),

\footnotetext{
${ }^{23}$ Surrey does use a few lines with no word boundary after position 4 in his rhymed verse, as in 'With form and fa-vour taught me to be-lieve' (Poem 13, 1. 3). He uses even more in his most important invention, blank verse, but this may be because, when he translated Virgil's Aeneid, he had access to the Scots version of Douglas, which is in Chaucer's metre.
} 
and in some he employs both (for example, 10 and 18). It should be noted that the English language, while having fewer oxytonic words than French in its word stocks, had deleted word-final schwa, making many more words oxytonic, and had vastly more monosyllables. ${ }^{24}$ This made an iambic vers de dix $(4+$ 6 ) a very good 'fit' for English phonology except in one respect: lyric caesura broke the iambic pattern unless wrenched in a way that is unpleasing to English ears. As a result Surrey seems to have abandoned lyric caesura and had occasional recourse to the running line, something he would have encountered in Wyatt's (and, perhaps, Douglas's) verse. Nevertheless, running lines constitute only 4 per cent of total in Surrey's rhymed verse, the same proportion that Billy 1999 finds in the décasyllabes of Jean Froissart (b.?1337, d. ?1410). These rare exceptions do not entitle us to classify either Froissart's or Surrey's lines as iambic pentameter.

There are a number of indications that Surrey's metre was experimental and tentative. The first is that his sonnets and other poems imitated from the Italian are composed in a very monosyllabic language: by my calculation 85 per cent of the words in Surrey's rhymed verse are monosyllables; and monosyllables make counting easy. He was also a notable experimenter in other ways: he invented both the 'Shakespearian' sonnet and blank verse. Surrey was the first English poet to realise that a pattern of five iambs is strong enough to be recognizable without the prop of either alliteration or rhyme. Surrey had no means of knowing that the future English canon would be the iambic pentameter of Chaucer and his Scottish followers, and, like Wyatt, he used the English long line as a field for experiment. That experiment failed because of its monotony of caesura, something that is unnecessary in an iambic line with its complex secondary rhythm.

24 Strang 1980: 288 notes a significant increase in monosyllables between the eleventh century and the sixteenth; by my calculation early Modern English texts comprise $\pm 75 \%$ monosyllables, Old French texts $\pm 60 \%$, and fourteenth-century Italian texts \pm 50\% (Duffell 2002: 305). 


\section{The English Line of Surrey}

The lack of a single, dominant long-line metre in the first half of the sixteenth century is evidenced by Surrey's cultivation of an alternative native metre. Many of his poems are composed in couplets derived from traditional English folk-verse. Their metre was called poulters'measure (because poulterers allegedly compensated for bad eggs by giving an extra one with every dozen). Poulter's measure is a syllabically regularized version of an English nursery rhyme metre:

(22) The grand old Duke of York,

(23) He had ten thou-sand men;

(24) He marched them up to the top of the hill,

(25) And he marched them down a-gain.

This rhyme, like most traditional English verse, is based on feet, or beats/offbeats and not syllable count: weak positions may contain two syllables if both are light. But poulter's measure eschews this double-occupancy and is syllable-based; its hemistichs contain 3, 3, 4, and 3 iambic feet. An example from Surrey is:

(26) Hot gleams of bur-ning fire and ea-sy sparks of flame

(27) In ba-lance of u-ne-qual weight he pon-de-reth by aim. (15. 7-8)

Although popular in the first half of the sixteenth century, this metre soon fell from use. This is probably because the fixed $3+3+4+3$ accentual structure becomes monotonous in long poems, and readers needed to stress all the syllables in strong positions in order to make the pattern in its anisosyllabic lines identifiable. By comparison the iambic pentameter has variety of accentual structure $(2+3$ and $3+2)$, and gains even more by making different strong positions prominent in different lines. The demise of poulter's measure cannot be attributed to a bad fit for the phonology of the language; it represents an aesthetic choice by English poets and audiences. 


\section{The English Line of Tusser}

Another metre that enjoyed considerable popularity in sixteenth-century England was also derived from folk-verse. As Ker 1898 first pointed out, its line structure is almost identical to that of the most popular long line in Castilian and Portuguese during a long period from around 1380 until the introduction of the endecasílabo (see n2 above and Gomez Bravo 1998). In Spain the metre was known by the generic title the verso de arte mayor ('the long-line verse'), in England it was called tumbling verse. Although derived from folk-verse, the English metre was employed by a number of educated poets and can be illustrated by the following lines by Thomas Tusser (b. ?1528, d. 1580). They are from Chapters 10 (81-82) and 13 (1-2) of the 1580 edition of his Five Hundred Points of Good Husbandrie (Payne \& Heritage 1878), the shorter first edition of which was published in the same year (1557) as Tottel's Miscellany.

(28) Good hus-band he trud-geth, to bring in the gaines

(29) good house-wife she drud-geth, re-fu-sing no paines

(30) V North winds send haile V, V South winds bring rain

(31) East winds we be-wail V, West winds blow a-main

Piera 1980: 109-14 argues that the verse design of the cognate Spanish metre is essentially amphibrachic, i.e. the line contains four feet, each of three syllables accented weak-strong-weak; this analysis is confirmed by Duffell 1999a: 65. In terms of parametric theory (which Hanson \& Kiparsky refrain from applying to triple-time verse (1996: 300)), such a verse design must be as follows: the template has eight positions orientated weak-strong; the correspondence rules make weak-position size equal one syllable, and strong-position size one syllable plus an optional post-tonic syllable; the prominence site/type constraints bar weak syllables from appearing in strong positions unless they share it with a preceding strong one. This verse design is most transparent in lines like (29), where word boundaries conveniently coincide with foot divisions. Note that in none of 
the quoted lines does the final strong position contain a posttonic syllable, nor in (30) and (31) does position 4 (scanned here as a void). Both hemistichs of this line also contain the most common source of variety in the metre, a void initial weak position.

The strong triple-time rhythm that runs through the quoted lines gives them a sing-song effect in stress-timed English; in syllable-timed Spanish such a rhythm appears 'sonorous but not melodious’ (Lázaro Carreter 1972: 377). This metre doubtless reminded its English readers of proverbs and traditional sayings, and was therefore admirably suited Tusser's content, helping endow it with rustic charm. Edmund Spenser (b. c.1552, d. 1599) also employed tumbling verse in a rural context: three sections ('May', 'July', and 'September') of his Shepheardes Calender (McCabe 1999: 23-156) are in this metre. In later centuries tumbling verse fell into disuse, although a closely related metre called the four-ictic dol'nik prospered (Tarlinskaja 1976: 10822). Two syllables are the maximum, rather than normal, weakposition size in the dol'nik, as, for example, in The Statue and the Bust (Williams 1954: 113-2) by Robert Browning (b. 1812, d. 1889). In contrast to the multi-purpose iambic pentameter, the dol'nik has mainly been chosen for verse in an informal register, and true tumbling verse, with a stress on every third syllable, has endured only as a vehicle for special effects. Thus in Browning's How They Brought the Good News from Ghent to Aix (Williams 1954: 16-18) the tumbling verse emphasizes the galloping content of the poem. Although they have become limited in their use, the dol'nik and its antecedent tumbling verse were the strongest native candidates for the long-line canon. Both evolved from Old English four-beat verse, and it is a measure of how much the English language has changed that they no are longer a better fit for it than the iambic pentameter, 'the rhythm of the foreigner', as Saintsbury called it (1906: 75; see also Lewis 1898: passim). 


\section{The French Line of Sidney and Spenser}

An important period in the development of a canonical long-line English metre was the years around 1580, when Sir Philip Sidney (b. 1554, d. 1586) completed Arcadia and began Astrophel and Stella, and Spenser was working on the Faerie Queene. Sidney and Spenser were familiar with sonnets in French and Italian composed, as I have noted, in two very different metres. The closest geographically of these two influences was undoubtedly the French, but that language no longer enjoyed the privilege of being the official language of England as it had been in Chaucer's and Gower's time. By 1580 French sonneteers had adopted the alexandrin. This gave the generation of poets active in England in 1580 another possible basis for an English longline metre, and both Sidney and Spenser experimented with it. As in Surrey's experiments with the vers de dix, they realized that English phonology favoured a stress-syllabic version of the metre.

The first sonnet of Astrophel and Stella (Bullett 1947: 173) is one of seven in which Sidney employed the longer metre. Its lines are strict French alexandrins, lines of 12M syllables divided by a word break after syllable 6; for example, the poem opens:

(32) Lo-ving in truth, and fain in verse my love to show

(33) That she, dear she, might take some plea-sure from my pain

(34) Plea-sure might cause her read, rea-ding might make her know

(35) Know-ledge might pi-ty win, and pi-ty grace ob-tain

These lines, unlike iambic pentameters, are made up of two symmetrical and unvarying rhythmic units. Their metre is a double iambic trimeter, which should not be classed as a hexameter since the structure of the two hemistichs is identical (both are always 6M syllables, never 6F) and there is no metrical interaction between them. First-foot inversion is allowed in both hemistichs and half of the eight quoted here have it. Sidney seems to have cultivated initial inversion as an antidote to the rhythmic monotony of lines with an invariable $3+3$ stress pattern. 
Although instance (32), like many French vers de dix and alexandrins, has enjambment between the hemistichs, no line fails to contain a word break after syllable 6 . Sidney's choice of the alexandrin for some of his sonnets was undoubtedly influenced by contemporary French practice; that he composed so few in the metre (seven out of 108 in Astrophel and Stella) suggests that he found some features of the Italian endecasílabo more aesthetically pleasing..$^{25}$

Spenser, too, was attracted by the alexandrine when he came to compose the Faerie Queene (probably in 1580, perhaps in late 1579, the year in which the Shepheardes Calender was published). The Faerie Queene's strophe consists of eight pentameter lines followed by one in the longer French measure. Spenser's alexandrin, however, has a striking innovation: the line is no longer $6+6$ syllables; it is 12 syllables in total. The following lines $(27,36,54$, and 81$)$ are from Canto I of the First Book of the Faerie Queene (Hamilton 1966: 80-100):

(36) U-pon his foe, a Dra-gon, hor-ri-ble and stearne

(37) And by her in a line a milke white lambe she lad

(38) And this faire cou-ple eke to shroud them-selves were fain

(39) The car-ver Holme, the Ma-ple seel-dom in-ward sound

Spenser's line is a unified hexameter: instances (36) and (39) have first hemistichs of 6F syllables and this is compensated in a second, which contains only $5 \mathrm{M}$, thus preserving the syllable count of 12M. This type of compensation (termed coupe italienne in the vers de dix) is unknown in either the French alexandrin or its Italian derivative. ${ }^{26}$ And this compensation is

${ }^{25}$ One feature of the endecasillabo that Sidney did not imitate was its almost invariable feminine ending; all lines in the sonnets of Astrophel and Stella have either $10 \mathrm{M}$ or $12 \mathrm{M}$ syllables. Sidney appears to have regarded the line of $10 \mathrm{~F}$ as a separate metre and uses it only in strophes of mixed line lengths (see Bullett 1947: 213 and 215). Spenser was equally fastidious in finding masculine rhymes for the Faerie Queene.

26 When Italian poets began to imitate the French alexandrine in the eighteenth century, they made the line a settenario doppio (double hexasyllable) of $6 \mathrm{~F}+6 \mathrm{~F}$ syllables, with thirteen syllables to the last stress in the line (see Elwert 1973: 79-80). The settenario doppio thus resembles the earliest medieval French alexan- 
what converts Spenser's line into a true hexameter, a unified dodecasyllable, with twelve syllables and six feet, in contrast to Sidney's alexandrin, which is a double trimeter of six and three. ${ }^{27}$ Although Spenser's innovation added a measure of syllabic variety to the alexandrin that its model lacked, this did not lessen the accentual monotony $(3+3)$ of an English stresssyllabic version. In the Faerie Queene Spenser offers a choice to subsequent English poets: pentameter or hexameter. In his stanza the pentameter predominates (in the ratio 8:1) for a good aesthetic reason: the opposite ratio would have been much more monotonous. Had he reversed the proportions, it is doubtful whether the resulting poem would have been as popular or influential as it turned out to be.

\section{The Italian Line of Sidney and Spenser}

Hanson 1996: 80 attributes the rediscovery of the iambic pentameter to Sidney, who, like Chaucer, knew Italian and spent a substantial amount of time in Italy. There he would have learned to appreciate the variety provided by a line with an unobtrusive iambic rhythm and no fixed mid-line word boundary. ${ }^{28}$ Although he thought a fixed caesura appropriate to his alexandrins, in his decasyllabic verse he adopted and adapted the endecasillabo, just as Chaucer had done. The following lines, which open Sonnet Ix of Astrophel and Stella, illustrate Sidney's mastery of the metre and, in particular, his skill (far greater than

drines with epic caesura (see Kastner 1903: 144), or lines of medieval Spanish cuaderna vía, which were modelled on the French (see Duffell 1999b: 151-54).

${ }^{27}$ Although the alexandrin has never rivalled iambic pentameter in popularity, both Sidney's divided and Spenser's unified variants have continued into modern times. Poem 48 of A Shropshire Lad (Sparrow 1956: 83) by A. E. Housman (b. 1859, d. 1936) is a modern example of a poem in divided alexandrins, and Non sum qualis eram bonae sub regnae Cynarae (Gardner 1972: 807) by Ernest Dowson (b. 1867, d. 1900) is a modern poem in unified ones. Dowson's lines are probably the most fluent and effective use of the metre in the English language.

${ }^{28}$ Hanson 1996 uses as her examples of the Italian line the endecasillabi of Dante and Petrarch, but Sidney would probably also have encountered Tasso's poetry of the 1560s, composed in endecasillabi that were much closer to his own English pentameters (see $n 7$ above). 
Surrey's) in deploying polysyllabic words of different accentual configurations:

(40) Queen Vir-tue's court, which some call Ste-lla's face

(41) Pre-par'd by Na-ture's choi-cest fur-ni-ture

Thompson (1961: 139-55) argues that Sidney occupies a pivotal position in the development of EIP, because he adjusted the natural rhythms of English phrases to the iambic verse design more skilfilly than any poet before him. But this is more the result of his skilful employment of monosyllabic stress than of his cultivation of variety in midline word breaks. In the latter he was no more skilled than Dunbar: the proportion of flowing lines (like (41) above) is very close to the 24 per cent found in Chaucer's early pentameters, and well below the 30 per cent found in the Canterbury Tales (see Duffell 2000b: 285 and 2002: 305).

Spenser, on the other hand, employed mid-line word-boundary variation more skilfully than any of his predecessors. This can be seen from the following lines (19-21 and 25) of Canto I of the First Book of the Faerie Queene: they illustrate the rhythmic subtlety of the iambic pentameter and every mid-line word configuration that can be accommodated within it:

(42) U-pon a great ad-ven-ture he was bond

(43) That grea-test Glo-ri-a-na to him gave

(44) That grea-test glo-rious Queene of Fae-rie lond

(45) To prove his pu-i-ssance in bat-tell brave

While (42) has a word break at position 4, (43) has a single word in positions 4-7, (44) one in 4-5, and (45) one in 4-6. According to my calculations, some 30 per cent of Spenser's lines have no word break immediately following syllable 4, and this became the canonical proportion of subsequent English poetry (Duffell 2002: 305).

Spenser was undoubtedly a superb metrical artist; George Saintsbury (1906: 350-58) and John Thompson (1961: 88-127) 
rightly acknowledge the enormous contribution made by the Shepheardes Calender to the development of English stresssyllabic metrics. ${ }^{29}$ By the time William Shakespeare (b. 1564, d. 1616) came to write poems and plays in iambic pentameter, poets and audiences had internalized its rules, and every poet who subsequently employed it helped imprint those rules even more deeply in readers' minds. The canon was thus a selfreinforcing phenomenon and, after a stuttering start, the iambic pentameter went on to dominate English long-line versifying for four centuries. Its ghost still haunts much of the free verse that has replaced it in popularity today: while many modern poets' lines are defined by nothing but right-boundary irrationality, a substantial proportion of them can be sensed as echoes of the canon, virtual iambic pentameters.

\section{Conclusion}

To conclude, the struggle to develop an enduring long-line metre in English was a protracted one and ended only in the late sixteenth century. Although a number of other metres had some potential to become the canon, the examples of Sidney, Spenser, and Shakespeare were decisive in ensuring the victory of iambic pentameter. A long series of subsequent poets endorsed their choice, and the iambic pentameter's dominance was only challenged at the end of the nineteenth century, when the panEuropean vogue for free verse swept over it and around it. While French metrics remained a rock that survived intact for almost a thousand years, English versification changed beyond recognition between 1066 and 1580. In the resultant metrical popularity contest the iambic pentameter emerged victorious for reasons that were linguistic, aesthetic, and sociological. It had in its favour that it was a good fit for the language, and that it offered a mixture of regularity and variety, appealing to the human desire for both security and stimulation. But it was also

29 Thompson devotes more than one third of The Founding of English Metre to Spenser and Sidney. 
fortunate in attracting at an early stage in its development poets whose work would be read and reread by later generations.

\section{WORKS CITED}

ATTRIDGE, DEREK, 1982. The Rhythms of English Poetry, English Language Series, 14 (London: Longman).

BALDI, SERGIO, 1953. La poesia di Sir Thomas Wyatt (Florence: Le Monnier).

BAWCUTT, PRISCILLA, \& FELICITY RIDDY, ed., 1992. Selected Poems of Henryson and Dunbar, The Scottish Classics, 16 (Edinburgh: Scottish Academic Press).

BILLY DOMINIQUE, 1989. 'Quelques apports récents à la métrique française’, Bulletin de la Société de Linguistique de Paris, 84: 283-319.

—, 1999. 'Le Décasyllabe rénové de Froissart', Romania, 117: 508-44.

—, 2001. 'Accent et metre dans le vers français apropos un livre de R. Pensom', unpubl. paper circulated in the Département de Lettres Modernes, Univ. de Nantes.

BRADLEY, A. C., 1970. 'Monosyllabic Lines and Words', in Literary English since Shakespeare, ed. George Watson (London: Oxford UP), pp. 50-64.

BULLETT, GERALD, ed., 1947. Silver Poets of the Sixteenth Century, Everyman's Library, 985 (London: J. M. Dent \& Sons).

CHATMAN, SEYMOUR, 1965. A Theory of Meter (The Hague: Mouton).

CLARKE, DOROTHY CLOTELLE (1964), Morphology of Fifteenth Century Castilian Verse, Duquesne Studies, Philological Series, 4 (Pittsburgh: Duquesne UP; Louvain: Nauwelaerts).

CORNULIER, BENOÎT DE, 1995. Art poëtique: notions et problèmes de métrique (Lyon: Presses Universitaires de Lyon).

DOMÍNGUEZ CAPARRÓS, JOSÉ, 2000. Métrica española, $2^{\text {nd }}$ ed. (Madrid: Editorial Síntesis).

DOMINICY, MARC, 1992. 'On the Meter and Prosody of French 12-Syllable Verse', in Foundations of Verse, ed. M. Grimaud, special issue of Empirical Studies of the Arts, 10: 157-81.

- , in press. 'Tendances du décasyllabe espagnol au XXe siècle', festschrift paper, to appear.

DUFFELL, MARTIN J., 1991. 'The Romance Hendecasyllable: An Exercise in Comparative Metrics', doctoral thesis, Queen Mary and Westfield College, Univ. of London.

-, 1996. 'Chaucer, Gower, and the History of the Hendecasyllable', in English Historical Metrics, ed. C. J. McCully \& J. J. Anderson (Cambridge, Eng.: Cambridge UP), 210-18. 
-, 1999a. Modern Metrical Theory and the 'Verso de arte mayor', PMHRS, 10 (London: QMW).

—, 1999b. 'The Metric Cleansing of Hispanic Verse', Bulletin of Hispanic Studies (Liverpool), 76: 151-68.

—, 2000a. 'Lydgate's Metrical Inventiveness and his Debt to Chaucer', in Kenedy 2000: 227-49.

-, 2000b “"The Craft So Long to Lerne": Chaucer's Invention of the Iambic Pentameter', Chaucer Review, 34 (1999-2000): 269-88.

—, 2002. 'The Italian Line in English after Chaucer', Language and Literature, 11: 291-305.

- in press. 'French Symmetry, Germanic Rhythm, and Spanish Meter', in Medieval Studies in Honor of H. A. Kelly, ed. Donka Minkova \& Theresa Tinkle (Bern: Peter Lang Verlag), to appear.

ELWERT, W. TH., 1973. Versificazione italiana dalle origini ai giorni nostri (Florence: Le Monnier).

ENDICOTT, ANNABEL M., 1963. 'A Critical Study of Metrical Effects in the Poetry of Sir Thomas Wyatt, with Reference to Analogous Effects in Elizabethan Poetry', MA diss., Univ. of London.

GARDNER, HELEN, ed., 1972. The New Oxford Book of English Verse, 1250-1950 (Oxford: Clarendon Press).

GASPAROV, 1987. 'A Probability Model of Verse (English, Latin, French, Italian, Spanish, Portuguese)', tr. Marina Tarlinskaja, Style, 21: 322-58.

GRAMMONT, MAURICE, 1937. Le Vers français: ses moyens d'expression, son harmonie, 4th ed. (Paris: Delagrave).

HAMILTON, A.C. ed., 1966. Edmund Spenser. Selected Poetry (London: New English Library).

HANSON, KRISTIN, 1996. 'From Dante to Pinsky: A Theoretical Perspective on the History of the English Iambic Pentameter', Rivista di Linguïstica, 9: 53-97

—, \& Paul Kiparsky, 1996. 'A Parametric Theory of Poetic Meter', Language, 72: 287-335.

KASTNER, L. E., 1903. A History of French Versification (Oxford: Clarendon Press).

KEENE, DENNIS, ed., 1985. Henry Howard, Earl of Surrey. Selected Poems (Manchester: Carcanet).

KENNEDY, RUTH, ed. 2000. Medieval English Measures: Studies in Metre and Versification, special issue of Parergon, n.s. 18.1 (July).

KER, W.P., 1898. 'Analogies between English and Spanish Verse (Arte mayor)', Transactions of the Philological Society, 113-28.

KIPARSKY, PAUL, 1977. 'The Rhythmic Structure of English Verse', Linguistic Inquiry, 8: 189-247.

JAKOBSON, ROMAN, 1973. 'Principes de versification', in Questions de poétique, ed. T. Todorov, tr. Léon Robel (Paris: Éditions du Seuil), pp. 40-55. 
JEFFERSON, JUDITH A., 2000. 'The Hoccleve Monograph and Hoccleve's Metrical Practice: More than Counting Syllables?', in Kennedy 2000: 203-26.

LÁZARO CARRETER, FERNANDO, 1972. 'La poética del arte mayor castellano', in Studia hispanica in honorem R.. Lapesa,I (Madrid: Gredos \& Cátedra Seminario Menéndez Pidal), pp. 343-78.

LEWIS, CHARLTON M., 1898. The Foreign Sources of English Versification (New York: H. Holt).

LOTE, GEORGES, 1939. 'Les Origines des vers français', Annales de la Faculté des Lettres d'Aix, 21: 219-25.

MCCABE, RICHARD A., ed., 1999. Edmund Spenser: The Shorter Poems (Harmondsworth: Penguin).

MINKOVA, DONKA, 1991. History of Final Vowels in English (Berlin \& New York: Mouton de Gruyter).

PAYNE, W., \& SIDNEY J. HERITAGE, ed., 1878. Thomas Tusser. Five Hundred Pointes of Good Husbandrie (London: Trübner \& Co).

PENSOM, ROGER, 1982. Literary Technique in the 'Chanson de Roland' (Geneva: Droz).

-, 2000. Accent and Metre in French: A Theory of the Relation between Linguistic Accent and Metrical Practice in French, 1100-1900 (Bern: Peter Lang).

PIERA, CARLOS JOSÉ, 1980. 'Spanish Verse and the Theory of Meter', doctoral thesis, Univ. of California, Los Angeles. DAI, 42 (1981-82): 197a.

RAVEN, D. S., 1965. Latin Metre: An Introduction (London: Faber and Faber).

REBHOLZ, R. A., ed., 1978. Sir Thomas Wyatt, The Complete Poems (Harmondsworth: Penguin).

ROLLINS, H. E., ed., 1928-29. Tottel's Miscellany of 1557, 2 vols (Cambridge MA: Harvard UP).

SAINTSBURY, GEORGE, 1906. A History of English Prosody from the Twelfth Century to the Present Day, I, From the Origins to Spenser (London: Macmillan).

SCHICK, JOSEF, 1889. Prologomena zu Lydgate's 'Tempel of Glas' (Berlin: the author, printed by H.S. Hermann).

SCOTT, TOM, ed., 1967. Late Medieval Scots Poetry: A Selection from the Makars and their Heirs down to 1610 (London: Heinemann).

SMITH, BARBARA HERRNSTEIN, 1968. Poetic Closure: A Study of How Poems End (Chicago: Chicago UP).

SPARROW, JOHN, ed., 1956. A.E. Housman. Collected Poems (Harmondsworth: Penguin).

STEELE, ROBERT, ed., 1941. The English Poems of Charles of Orleans, EETS, o.s. 215 (London Oxford UP). 
—, \& Mabel Day, ed., 1946. The English Poems of Charles of Orleans, EETS, o.s. 220 (London: Oxford UP).

STRANG, BARBARA M.H., 1980. 'The Ecology of the English Monosyllable', in Studies in English Language, ed. S. Greenbaum, Geoffrey Leech, \& J. Svartik (London: Longman), pp. 277-93.

TARLINSKAJA, MARINA, 1976a. English Verse: Theory and History, translated from the Russian by the author, De Proprietatibus Litterarum: Series Practica, 17 (The Hague: Mouton).

THOMPSON, JOHN, 1961. The Founding of English Metre (London: Routledge \& Kegan Paul; New York: Columbia UP).

VERLUYTEN, PAUL, 1982. 'Recherches sur la prosodie et la métrique du français', doctoral thesis, Univ. Instelling, Antwerp.

—, 1989. 'L'Analyse de l'alexandrin: Mètre ou rhythme', in Le Souci des apparences: neuf études de poétique et de métrique, ed. Marc Dominicy (Brussels: Éditions de l’Université), pp. 31-74.

VIANELLO, NEREO, ed., 1966. Francesco Petrarca. Il canzoniere (Basiano: Bietti).

VOLKOFF, VLADIMIR, 1978. Vers une métrique française (Columbia SC: French Literature Publications Company).

WILLIAMS, W. E., ed., 1954. Browning: A Selection (Harmondsworth: Penguin). 